\title{
ANNOUNCEMENT
}

The IXth International Symposium of the

SOCIETY FOR ANAEROBIC MICROBIOLOGY will be held at

Churchill College, Cambridge on Friday and Saturday, July 14 and 15, 1995

"Anaerobic pathogens"

Friday July 14. Session 1: Virulence factors.

I. Poxton (Edinburgh); A. O. Tzianabos (Boston, USA); S. Patrick (Belfast).

Session 2: The oral anaerobic ecosystem

A joint session with the PATHOLOGICAL SOCIETY OF GREAT BRITAIN AND

IRELAND. H. N. Shah (London); B. G. Loos (Amsterdam); S. E. Gharbia (London)

Saturday July 15. Session 3: Novel methodology

A. R. Eley (Sheffield); A. L. M. Hodgson (Victoria, Australia); D. B. Drucker (Manchester);

G. O'Neill (Cardiff)

Session 4: Antibiotics

D. Greenwood (Nottingham); H. Wexler (Los Angeles, USA); D. Edwards (London)

Session 5: Clinical anaerobic infections

B. I. Duerden (Cardiff); S. Hillier (Pittsburgh, USA); D. Murdoch (Bristol)

$\begin{array}{llll} & \text { Before } & \text { After } & \text { Day } \\ \text { Registration } & \text { June 1 } & \text { June 1 } & \text { registration } \\ \text { SAM/Path. Soc members } & £ 150 & £ 175 & £ 40 \\ \text { Non-members } & £ 175 & £ 200 & £ 50\end{array}$

A $10 \%$ reduction on these prices is available for members of the Institute of Biomedical Sciences.

Registration includes lunch and symposium dinner (July 14), bed and breakfast (July 14), lunch (July 15), tea and coffee.

Further information from: Dr Adrian Eley,

Department of Medical Microbiology,

University of Sheffield Medical School,

Beech Hill Road,

Sheffield S10 2RX

Tel: 01142712335

\section{Society for Applied Bacteriology}

Symposium: Mycobacterial Disease: Problems and Solutions, University of Southampton, 19-21 July 1995

The Society's choice of this subject for the annual Summer Conference is particularly timely because of the recent resurgence of infection with Mycobacterium tuberculosis, first recognised in the United States in the wake of the HIV pandemic. Though infection with

$M$. avium-intracellulare is well recognised in the UK, the hazards associated with an increase in the incidence of tuberculosis deserve to be better recognised. It seemed that tuberculosis had been conquered in the developed world by a combination of socio-economic advance and BCG immunisation. Drugs were available to treat the few cases of the disease that remained.

Similarly, bovine tuberculosis had been eradicated by milk pasteurisation and cattle slaughter policies. It was in part this success in dealing with tuberculosis that led to the recognition of diseases due to what came to be known as the 'Anonymous Mycobacteria'.

In part 1 of the symposium 'The Problems' will be considered from a basic vantage point, beginning with the biology of the genus Mycobacterium (J. M. Grange, London) and their 
virulence determinants (P. W. Andrew, Leicester), followed by discussions of resurgence of tuberculosis (P. O. Davies, Liverpool), the bovine tuberculosis cycle (C. Daborn, Edinburgh) and the present situation with regard to leprosy (M. J. Colston, London). Other topics will include the problem of environmental mycobacteria (P. A. Jenkins, Cardiff), $M$. intracellulare and its association with AIDS (A. Posniak, London) and the possible role of mycobacteria in sarcoidosis and Crohn's Disease (J. J. McFadden, Guildford).

Part 2 will be devoted to 'Possible Solutions', notably the application of molecular biological methods to some current mycobacterial problems (P. D. Butcher, London), chemotherapy (D. A. Mitchison, London), the new anti-mycobacterial drugs (H. Gaya, London) and immunotherapy (J. Stanford, London). Finally, the important problem of the activity of biocides against mycobacteria (A. D. Russell, Cardiff) and the decontamination of endoscopes (R. Simpson, Hitchin) will concluded the symposium.

The distinguished cast of speakers and the importance of the subject will make this a most significant occasion in the 1995 calendar of scientific meetings. For further information, please, contact the Executive Secretary, Society for Applied Bacteriology, PO Box 510, Harrold, Bedford MK43 7YU (Tel. 01234 720047, Fax: 01234 720048). 